\begin{tabular}{|l|l|l|l|}
\hline Eiszeitalter u. Gegenwart & $\mathbf{3 3}$ & $\begin{array}{l}1-7 \\
4 \mathrm{fig} .\end{array}$ & Hannover 1983 \\
\hline
\end{tabular}

\title{
Distribution of the Heavy Minerals in the Downwind Tephra Lobe of the May 18, 1980 Eruption of the Mount St. Helens (Washington, USA)
}

\author{
Etienne Juvigné \& Susan Shipley *)
}

Correlation, marker bed, volcanic ash, heavy mineral, hornblende, hypersthene, quantitative special distribution, analyse, eruption, Upper Holocene.

Washington, Mount St. Helens

\begin{abstract}
Quantitative analysis of heavy minerals from tephra samples of the May 18 eruption of Mount St. Helens shows variations in the total content of heavy minerals as well as in the ratio hypersthene/hornblende. Both decrease along the lobe with increasing distance from the volcano and from the lobe margins to the axis. The basal dark-grey layer contains more hypersthene than the overlying light-grey layer. The observed sorting is a function of the specific gravity of the minerals, and grain shape. Variation across the lobe is attributed to the relative thicknesses of the dark- and light-colored layers.
\end{abstract}

\section{[Schwermineralverteilung im Verbreitungsgebiet der Aschen vom Ausbruch des Mount Saint Helens (Washington-U.S.A.) am 18. 5. 1980]}

Kurzfassung: Die stratigraphische Korrelation von vulkanischen Leithorizonten aufgrund ihrer Schwermineralzusammensetzung bringt Probleme mit sich, da die Frage, ob die Zusammensetzung im Verbreitungsgebiet konstant oder wechselnd ist, noch nicht eindeutig geklärt werden konnte. In Europa stellt sich dieses Problem im wesentlichen bei unterschiedlichen tuffitischen Lagen (Laachersee Tuff, Eltviller Tuff, Tuf de Rocourt). Dieser Beitrag betrifft die Aschen, die vom Mount Saint Helens-Vulkan am 18. 5. 1980 gefördert wurden. Davon wurden quantitative Analysen von Schwermineralien in der Absicht durchgeführt, tephrostratigraphische Probleme zu lösen. Es wurde nachgewiesen, daß der Gehalt an Schwermineralen mit der Entfernung vom Vulkan und zum Rand des Verbreitungsgebietes hin abnimmt. Die transparenten Schwerminerale bestehen im wesentlichen aus Hypersthen und basaltischer Hornblende. Das Verhältnis Hypersthen/Hornblende ändert sich schrittweise mit der Entfernung vom Vulkan und der Entfernung von der Hauptachse zum Rand des Verbreitungsgebietes. Die Ursachen liegen in der unterschiedlichen Dichte und Form der einzelnen Minerale. Änderungen innerhalb des Verbreitungsgebietes hängen ferner von der wechselnden Dicke der dunklen und hellen Schicht ab. Es ist auch nachgewiesen, daß die Prozentsätze der Schwermineralspektren innerhalb eines kleinen Gebietes, unter Berücksichtigung der Fehlergrenzen ( $95 \%$ Niveau), übereinstimmen.

\section{Introduction}

In the last 30 years tephra layers, and especially their content of heavy minerals, have been used as a basis for correlation of Quaternary deposits. In some cases, differences in the mineralogical content add to difficulties of correlating ash layers such as "Laachersee Tuff" (Juvigné 1977, 1983), "Eltviller Tuff“ (Bibus 1973; Juvigné \& Semmel 1981), "tuf de Rocourt" (Juvigné 1977b) and "retombé supérieure" (MARTINi 1971). Hence an important question is the variation in composition of a single ash-fall with distance from the source vent.

*) Addresses of the authors: Dr. E. J u vig n é, Université de Liège, Laboratoire de Géomorphologie et de Géologie du Quaternaire, Place du XX Août, 7 - 4000 Liège, Belgium. - S u s a n S hipley, Quaternary Research Center, University of Washington, Seattle, WA 98195. 
In this paper, the example of the May 18 eruption of Mount St. Helens is used to demonstrate the possibility of correlating ash layers whose heavy mineral contents are quantitatively different.

\section{Transparent heavy mineral suites of the dark and the light layers}

Preliminary analyses of the composition of the downwind basal dark-grey and overlying light-colored ash layer were reported by SARNA-WOJCICKI et al. (1981). Since this work, two layers have been distinguished within the light-colored layer: a light-grey unit overlain by a tan unit.

For this paper, samples from each layer were collected in July, 1982 at 6 localities along the axis of the lobe (Fig. 2). The tan layer was not discernible at the two westernmost localities, so analyses are limited here to bulk light-colored ash and elsewhere to the dark- and light-grey layers. Care was taken to remove any reworked or underlying material from the samples.

\section{Method}

All the samples were treated by the following method:

1. Wet sieve through screens of $500 \mu \mathrm{m}$ and $63 \mu \mathrm{m}$; avoid abrasion of samples during sieving.

2. Dry $63-500 \mu \mathrm{m}$ fraction in oven.

3. Separate in purified bromoform (density: 2.89) using a centrifuge (Juvigné 1979).

4. Mount heavy minerals in Canada balsam.

5. Count 200 transparent heavy minerals from each slide using the ribbon method.

\section{Results}

The most common heavy minerals are orthopyroxenes and amphiboles. Investigations by Kuntz et al. (1981) of deposits of the May 18 eruption have shown that all amphibole can be considered to be hornblende and all orthopyroxene to be hypersthene. Amphiboles can be essentially considered brown hornblende. Hypersthene plus amphiboles represent at least $95 \%$ of the total transparent heavy minerals of our samples. The other $5 \%$ consists of traces of clinopyroxenes and unknown minerals.

The percentages of amphiboles and orthopyroxenes from the 6 sites are shown in figure 2. At 5 of the 6 localities $(1,3,4,5$, and 6$)$ the dark-colored layer contains a higher amount of hypersthene and a lower amount of hornblende than the light-colored layer. After application of error at the 95.4 level of confidence only 1 of 6 values in each set does not overlap, both within the dark- and light-colored layers.

\section{Variation of transparent mineral suites in the lobe}

Bulk samples of tephra collected within 3 days after the May 18 eruption were analyzed. These samples were prepared using methods described earlier.

In figure 1, the values of the ratio hypersthene/hornblende have been plotted at the corresponding sampling sites. Isolines of this ratio have been added to suggest the main trend of variations. Isopach lines are also shown in figure 1 after SARNA-WOJCICKI et al. (1981, Fig. 336) to help position our results within the lobe. The ratio hypersthene/hornblende clearly decreases with distance from the volcano as well as from the margins of the lobe to its axis. 


\section{EXPLANATION}

- percentages relating to the light grey layer

- percentages Relating to the dark LAYER

I ERROR IN PERCENT AT THE 95,4 LEVEL OF CONFIDENCE

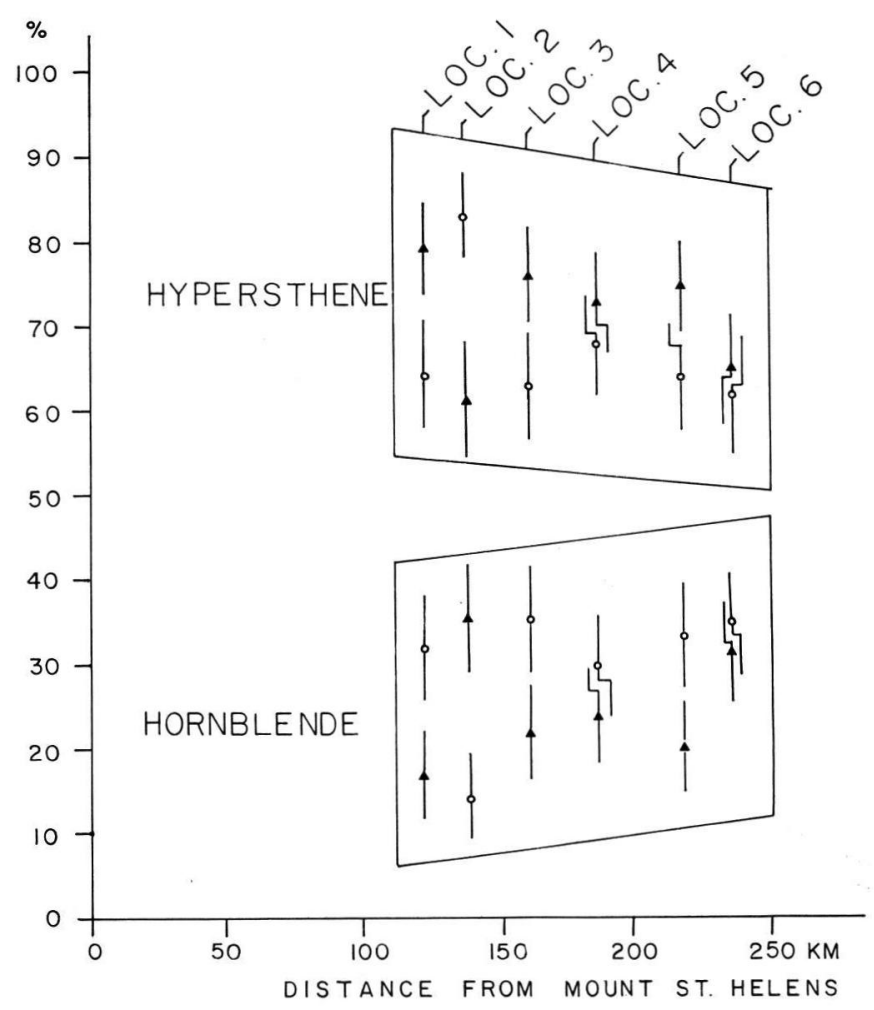

Fig. 1: Percentages of hypersthene and hornblende to all transparent heavy minerals from the dark and the light-grey layers from 6 localities along the axis of the lobe of the May 18 eruption of Mount St. Helens. Localities are shown in fig. 2.

Looking at the separate percentages, $9.5 \%$ to $17 \%$ hornblende and $81.5 \%$ to $89 \%$ hypersthene are present in the transect closest to source (about $130 \mathrm{~km}$ from the volcano) and $34 \%$ to $45 \%$ hornblende and $51 \%$ to $62.5 \%$ hypersthene occur in the far distal transect (about $600 \mathrm{~km}$ from the volcano). A similar trend can be recognized in figure 2 with respect to the percentages from the 12 samples of both the dark and light layers. Our observations indicate sorting of the transparent heavy minerals in the plume. Sorting along the lobe axis may be explained by a difference in specific gravity which is lower for hornblende (3 to 3.3) than for hypersthene (3.3 to 3.5). Differences in grain shape may also influence particle transport, the flatter, tabular hornblende travelling farther than the prismatic hypersthene.

We attribute the symmetrical variation of the hypersthene/hornblende ratios about the lobe axis to changes in the proportion of light-colored ash to dark throughout the lobe. The thickness of the lobe is controlled largely by variation in the thickness of the lightcolored (light-grey plus tan) layer (SARNA-WoJCicki et al. 1981, Fig. 339). The dark- 
grey ash remains relatively uniform in thickness across the lobe (SARNA-WoJCICKI et al. 1981, Fig. 340; D. Dzurisin, written commun., 1980; S. Shipley, unpub. data). Components of both dark- and light-colored layers were probably deposited as a mixed layer at the lobe margins. The higher percent of hornblende relative to hyperstene in the lightcolored layer corresponds well with the isopach map.

A comparison of our results with those of KunTz et al. (1981) to look for a trend from our westernmost transect to the source vent is not possible because the technical methods were not the same (Juvigné 1983) and the turbulence within the plume in the vicinity of the volcano was quite different than that downwind.
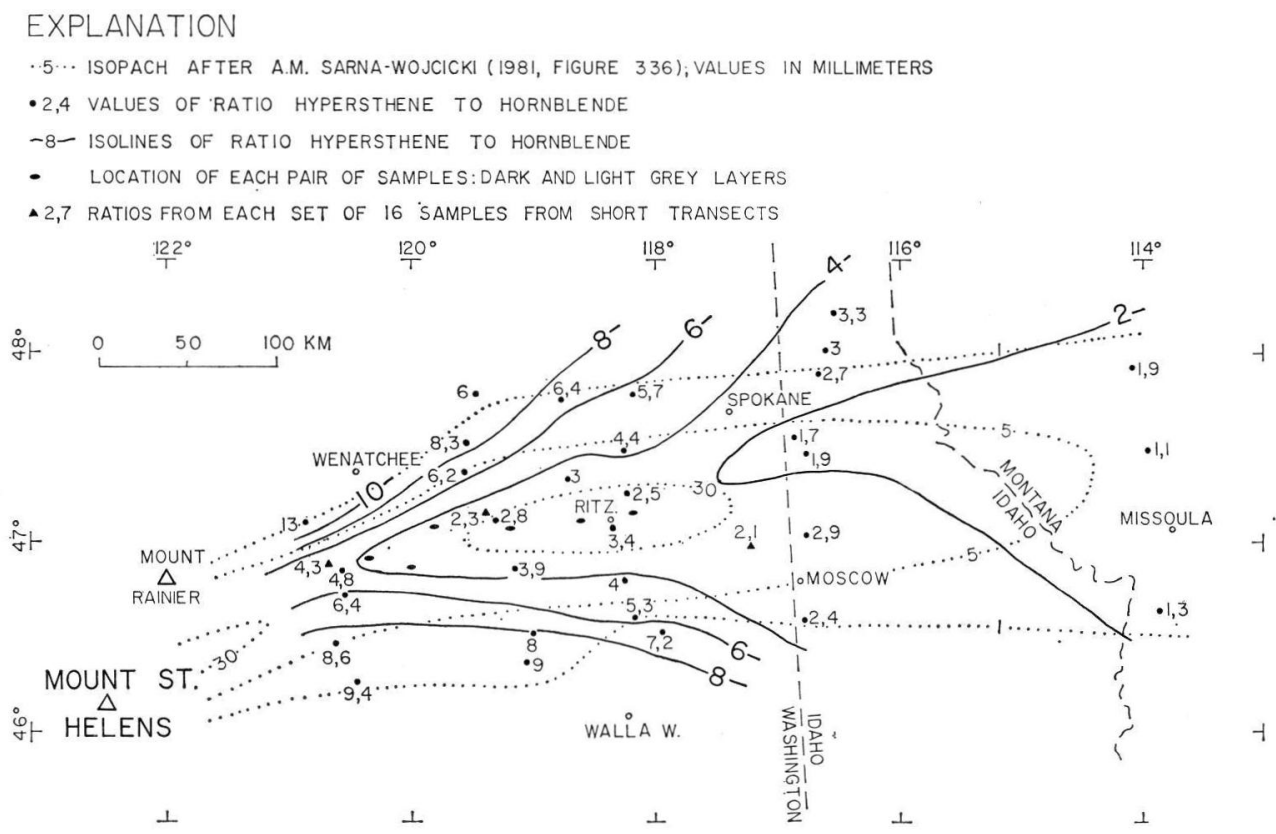

Fig. 2: Variation of ratio hypersthene/hornblende in the lobe of the May 18 eruption of Mount St. Helens.

\section{Variation of the heavy mineral suites along short transects}

This investigation is of particular importance to current European tephrostratigraphic research. Attempts to correlate thin, distal tephra layers within small areas (for example, JUVIGNÉ 1983) have been hindered by high variability among heavy mineral suites.

Three sets of 16 bulk samples were collected in September, 1982 to determine local variation within the heavy mineral suites. Each set was collected along transects about $1.5 \mathrm{~km}$ long; samples were taken about $100 \mathrm{~m}$ apart. Set 1 was collected approximately $60 \mathrm{~km}$ south of Wenatchee; set 2, about $75 \mathrm{~km}$ west of Ritzville; and set 3, about $100 \mathrm{~km}$ southwest of Spokane (Fig. 2). The preparation technique described earlier was applied to all samples.

The greatest deviations are $11 \%$ for hyperthene and $10 \%$ for hornblende, both in set 3 (Fig. 3). After application of standard error at the 95.4 level of confidence the 16 values overlap in each set both for hypersthene and hornblende. 


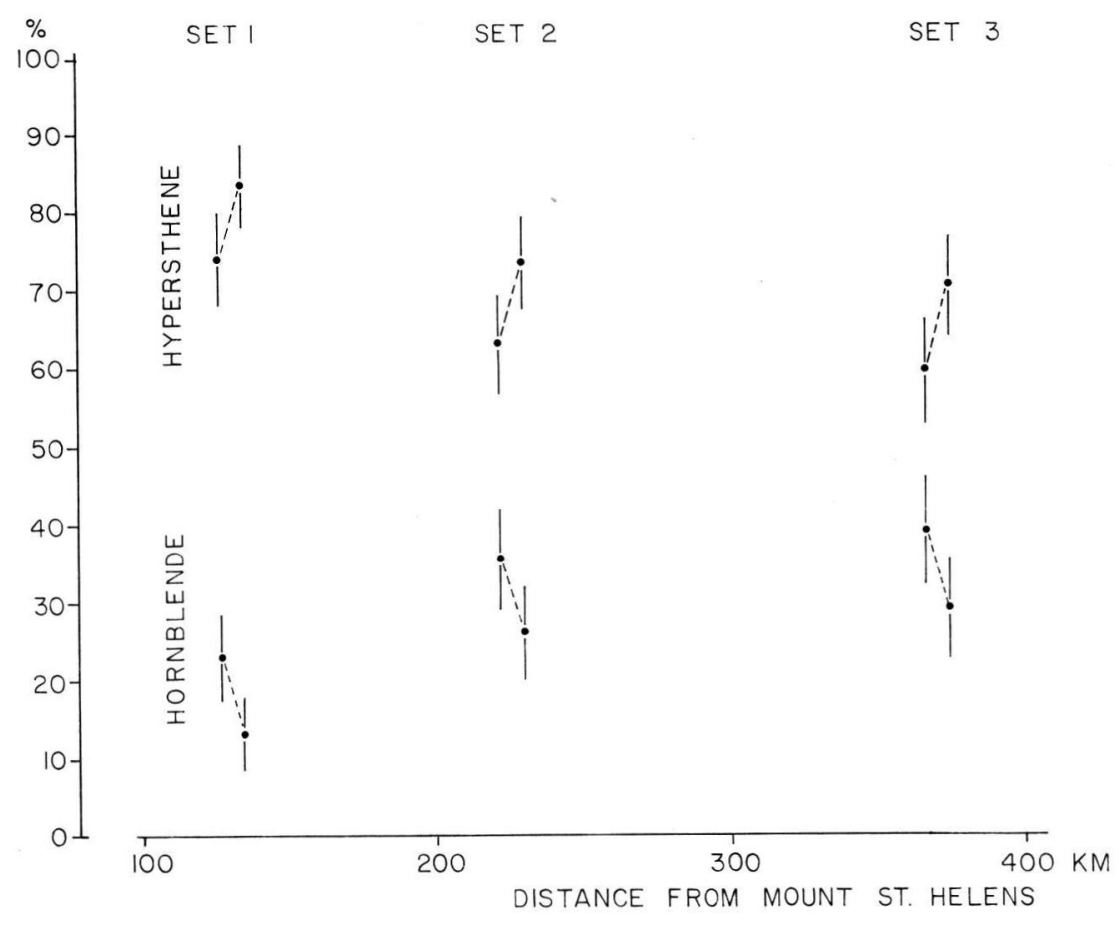

Fig. 3: Percentages of hypersthene and hornblende to all transparent heavy minerals for 3 sets of 16 bulk samples collected along short transects. Data points represent minimum and maximum values at each site; remaining values lie along the dashed lines. Vertical bars represent probable error at 95.4 confidence level.

In spite of the variations along each short transect, the mean values for each set of 16 samples are consistent with the general trend of variation of heavy mineral suites discussed earlier; mean values are plotted in figure 1.

\section{Variation of the amount of heavy minerals in the lobe}

The abundance of heavy minerals is highly variable throughout the lobe. Hence quantitative analyses were made to determine the exact amount of heavy minerals (transparent plus opaque) present.

\section{Method}

1. Dry bulk sample in oven.

2. Weigh $100 \mathrm{mg}$ from each sample.

3. Shake sample in $100 \mathrm{ml}$ purified bromoform using centrifuge tube. The density of bromoform was checked to be 2.89 when used.

4. Centrifuge 5 minutes at $4000 \mathrm{rpm}$.

5. Freeze the bottom of the centrifuge tube in nitrogen.

6. Shake the tube.

7. Repeat steps 4,5 , and 6 . 
8. Repeat steps 4 and 5.

9. Remove the floating light fraction and rinse tube with acetone.

10. Warm frozen bromoform, pour onto paper filter and rinse with acetone.

11. Weigh heavy minerals with a balance precise to $10^{-5} \mathrm{~g}$.

\section{Results}

The results are plotted as percentages in figure $4 \mathrm{a}$. In figure $4 \mathrm{~b}$ the lowest, the mean, and the highest percentages of each transect are represented with respect to distance from the volcano in order to sketch the trend of the variations. There is a clear decrease in the amount of heavy minerals downwind in the lobe. The amount in the Missoula transect is more than 100 times lower than that in the westernmost transect.

Variation among the values along each transect is not as great; the ratios between the highest and lowest values vary from about 2 (transect $75 \mathrm{~km}$ west of Ritzville) to 6 (Missoula transect). Moreover, the highest amount of heavy minerals is never at the margin of the lobe but does not correspond with the lobe axis.

\section{Conclusions}

Sorting of heavy minerals within the plume of the May 18 eruption of Mount St. Helens has been shown to be based on their specific gravity and grain shape. The amount

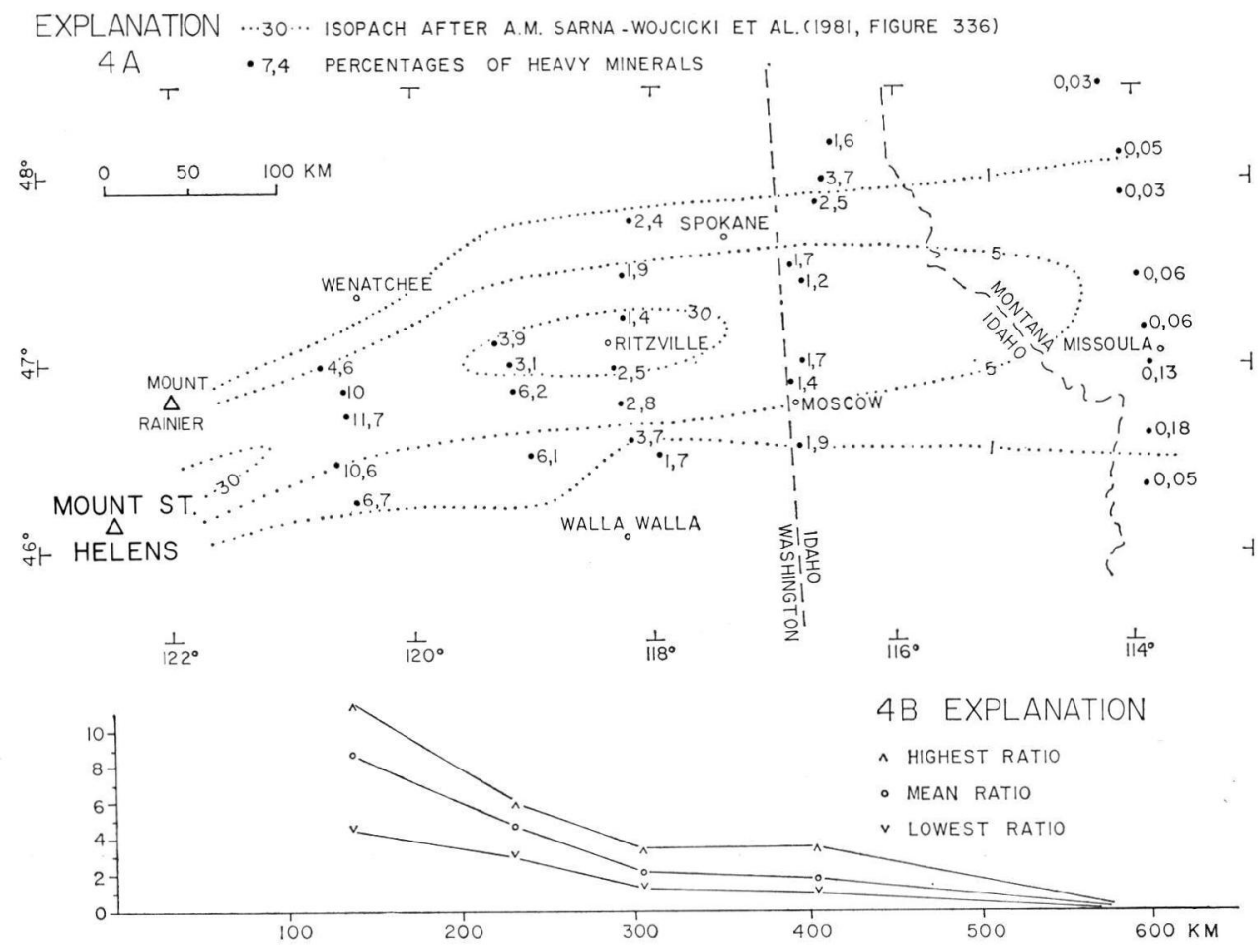

Fig. 4: Amount of heavy minerals (opaque and transparent) in bulk samples from the lobe of the May 18 eruption of Mount St. Helens: 4a. Percentages at different localities within the lobe $4 \mathrm{~b}$. Lowest, mean and highest percentages for each transect. 
of the heaviest particles decreases downwind from the volcano. This sorting agrees with other variations within the lobe as described by SARNA-WOJCICKI et al. (1981) for grain size and by FRUCHTER et al. (1981) for chemical composition.

One of the most important consequences of the sorting is the quantitative variation of the mineral assemblages within the lobe. Moreover, great variations of the heavy mineral suites occur locally, but after application of standard error, all values overlap.

Our results may be used for correlation of other ash layers using mineral assemblages, but further work is needed to evaluate variation in other minerals.

\section{Acknowledgments}

This research was conducted at the Quaternary Research Center, University of Washington, and was supported by a grant to one of us (E. Juvigné) from the North Atlantic Treaty Organization. The U.S. Geological Survey provided many of the bulk samples.

\section{References}

Bibus, E. (1973): Ausbildung und Lagerungsverhältnisse quartärer Tuffvorkommen in der Wetterau. - Notizbl. hess. L.-Amt Bodenforsch., 101: 346-361; Wiesbaden.

Fruchter, J. S., Robertson, D. E., Evans, J. C., Olsen, K. B., Lepel, E. A., Laul, J. C., Abel, K. H., Sanders, R. W., Jackson, P. O., Wogman, N. S., Perkins, R. W., Van Tuyl, H. H., Beauchamp, R. H., Shade, J. W., Daniel, J. L., Erikson, R. L., Sehmel, G. A., Lee, R. N., Robinson, A V., Moss, O. R., Briant, J. K. \& Cannon, W. C. (1980): Mount St. Helens ash characterizations, May 18,1980, eruptionchemical, physical, mineralogical and biological properties. - Science, 209: 1116-1125; Washington.

Juvigné, E. (1977a): La zone de dispersion des poussières emises par une des dernières éruptions du volcan du Laachersee (Eifel). - Z. Geomorph. N. F., 21: 323-342; Berlin-Stuttgart.

- (1977b): Zone de dispersion et âge des poussières volcaniques du tuf de Rocourt. - Ann. Soc. Géol. Belg., 100: 13-22; Liège.

- (1979): Scheidetrichtermethode oder Zentrifugaltrennung zur quantitativen Gewinnung von Schwermineralen. - Senckenbergiana marit., 11: 171-174; Frankfurt a. Main.

- (1983): Two different volcanic ash-falls of Alleröd age in High Belgium. - Geologie en Mijnbouw; s'Gravenhage. - [In press.]

- \& Semmel (1981): Un tuf volcanique semblable à l'Eltviller Tuff dans les loess de Hesbaye (Belgique) et du Limbourg néerlandais. - Eiszeitalter u. Gegenwart, 31: 83-90; Hannover.

Kuntz, M. A., Rowley, P. D., MacLeod, N. S., Reynolds, R. L., McBroome, L. A., Kaplan, A. M. \& LiDKe, D. F. (1981): Petrography and particle-size distribution of pyroclasticflow, ash-cloud, and surge deposits. In: P. W. Lipman \& D. R. Mullineaux (Eds.): The 1980 Eruptions of Mount St. Helens, Washington. - U.S.G.S. Prof. Paper, 1250: 525-539; Washington.

Martini, J. (1971): Recherche de retombées volcaniques quaternaires dans le sud-est de la France et la Suisse occidentale. - Arch. Sci. Gen., 23: 641-674; Genève.

Sarna-Wojcicki, A. M., Shiplex, S., WattT, R. B., Jr., Dzurisin, D. \& Wood, S. H. (1981): Areal distribution, thickness, mass, volume, and grain size of air-fall ash from the six major eruptions of 1980. - In: P. W. Lipman \& D. R. Mullineaux (Eds.): The 1980 Eruptions of Mount St. Helens, Washington. - U.S.G.S. Prof. Paper 1250: 577-600; Washington.

Manuscript accepted on 25. 1. 1983. 
